Hatton, D. C., Muntzel, M., McCarron, D. A., Pressley, M., \& Bukoski, R. D. (1988). Early effects of dietary calcium on blood pressure, plasma volume, and vascular reactivity. Kidney International, 34 (Suppl. 25), S16-S18.

Hazum, E. (1983). Hormones and neurotransmitters in milk. Trends in Pharmacological Sciences, 4, 454-456.

Keen, C. L., Lonnerdal, B., ClegG, M., \& Hurley, L. S. (1981). Developmental changes in composition of rat milk: Trace elements, minerals, protein, carbohydrate and fat. Journal of Nutrition, 111 , 226-230.

Koldovsky, O. (1980). Hormones in milk. Life Sciences, 26, 1833-1836.

Kurtz, T. W., Al-Bander, H. A., \& Morris, R. C. (1987). Saltsensitive essential hypertension in men: Is the sodium ion alone important? New England Journal of Medicine, 317, 1043-1048.

LovenberG, W., Simpson, F. O., \& YAMORI, Y., (Eds.) (1986). Contribution of hypertensive rat models to medicine. Joumal of Hyper tension, 4 (Suppl. 3), S1- S541.

Luckey, T. D., Mende, T. J., \& Pleasants, J. (1954). The physical and chemical characterization of rat's milk. Journal of Nutrition, 54 , 345-359.

MAcGregor, G. A. (1985). Sodium is more important than calcium in essential hypertension. Hypertension, 7, 628-637.

MCCARRON, D. A. (1985). Is calcium more important than sodium in the pathogenesis of essential hypertension? Hypertension, 7, 607-627.

MCCARRON, D. A. (1986). The calcium deficiency hypothesis of hypertension. Annals of Internal Medicine, 105, 947-955.

MCCARRON, D. A. (1989). Calcium metabolism and hypertension. Kidney International, 35, 717-736.
McCarty, R., Cierpial, M. A., Murphy, C. A., Lee, J. H., \& FIELDS-OKотсHA, C. (1992). Maternal involvement in the development of cardiovascular phenotype. Experientia, 48, 315-322.

McMurty, J. P., Wright, G. L., \& WeXler, B. C. (1981). Spontaneous hypertension in cross-suckled rats. Science, 211, 1173-1175.

Muntzel, M. S., Hatton, D. C., Metz, J. A., McCarron, D. A. (1989). Dietary calcium alters blood pressure in neonatal spontaneously hypertensive rats. American Journal of Hypertension, 2, 158-162.

MURPhy, C. A., \& McCARTY, R. (1989). Maternal environment and development of high blood pressure in Dahl hypertensive rats. American Journal of Physiology, 257, H1396-H1401.

Окомото, К. (Ed.) (1972). Spontaneous hypertension: Its pathogenesis and complications. Tokyo: Igaku Shoin.

Rascher, W., Clough, D., \& Ganten, D. (Eds.) (1982). Hypertensive mechanisms: The spontaneously hypertensive rat as a model to study human hypertension. Stuttgart: F. K. Schattauer.

Sowers, J. R., Zemel, M. B., Standley, P. R., \& Zemel, P.C. (1989). Calcium and hypertension. Journal of Laboratory \& Clinical Medicine, 114, 338-348.

Whelton, P. K., \& KLAG, M. J. (1989). Magnesium and blood pressure: Review of the epidemiologic and clinical trial experience. American Journal of Cardiology, 63, 26G-30G.

ZichA, J., KUNES, J., \& JELINEK, J. (1986). Experimental hypertension in young and adult animals. Hypertension, 8, 1096-1104.

(Manuscript received September 9, 1992; revision accepted for publication September 23, 1992.)

\title{
Notice
}

\section{Nominations for the Editorship of Psychobiology}

Nominations are solicited for the editorship of Psychobiology. The term of the present editor, Paul E. Gold, expires at the end of 1994. The new editor will begin an official 4-year term January 1, 1995. It is expected that the Publications Committee of the Psychonomic Society will make the appointment by June 1993.

Nominations must be submitted by April 30, 1993.

Nominations (including self-nominations) should be sent to:

Douglas L. Medin

Department of Psychology

Northwestern University

2029 Sheridan Road

Evanston, IL 60208 